\title{
ЗМІНИ ОСНОВНИХ ПОКАЗНИКІВ ЧЕРВОНОЇ КРОВІ У ХВОРИХ НА СТЕАТОГЕПАТИТ РІзНої ЕТІОЛОГІї
}

\author{
๑О. С. Хухліна, Т. М. Антофійчук, М. П. Антофійчук, О. В. Каушанська \\ ВДнз України «Буковинський державний медичний університет», м. Чернівці
}

РЕЗЮМЕ. Основними причинами стеатогепатиту печінки $\epsilon$ вплив на неї токсичних речовин, ендокринні порушення, неправильне харчування. Особливе місце серед токсичних агентів займає алкоголь.

Мета - дослідити зміни основних показників червоної крові при стеатогепатиті різної етіології.

Матеріал і методи. Проведено клінічне спостереження за 60 хворими на алкогольну хворобу печінки та неалкогольний стеатогепатит. Серед обстежених 53,3 \% становили чоловіки, 46,7 \% - жінки. Усіх хворих було поділено на дві групи: до першої (I) ввійшли 33 \% пацієнтів з алкогольною хворобою печінки (алкогольним стеатогепатитом - АСГ), до другої (II) - 67 \% хворих із неалкогольною жировою хворобою печінки (неалкогольний стеатогепатит - НАСГ). Контрольну групу склали 20 практично здорових осіб (ПЗО), в яких не виявлено гострих чи хронічних захворювань та алергічних проявів.

Результати. При дослідженні показників клінічного аналізу крові встановлено, що вміст еритроцитів у периферичній крові хворих на НАСГ був у межах норми, а у хворих на АСГ даний показник був вірогідно нижчий за показник у П30 на 9,0 \% (р<0,05). Разом з тим, вміст гемоглобіну у хворих цієї ж групи вірогідно відрізнявся від вікової норми і був істотно нижчий від показника у П3О на 8,5% (p<0,05), а це свідчить, що в частини хворих на АСГ встановлено анемічний синдром.

Висновок. Перебіг алкогольного стеатогепатиту у 25,0 \% випадків супроводжується анемічним синдромом легкого ступеня, незважаючи на істотне вірогідне підвищення в сироватці крові вмісту заліза, феритину, насичення трансферину залізом. Причому, в 15,0 \% хворих на АСГ анемія зумовлена дефіцитом вітаміну В , $_{12}$ у 10,0 \% гемолізом еритроцитів. Описано, що на тлі ожиріння перебіг неалкогольного стеатогепатиту характеризується невірогідним зростанням показників вмісту заліза в сироватці крові, вмісту феритину та насичення трансферину залізом за відсутності клініко-лабораторних ознак анемії.

КлючОВІ СлОВА: неалкогольний стеатогепатит; алкогольний стеатогепатит; анемічний синдром; ожиріння.

Вступ. Основними причинами стеатогепатиту печінки $\epsilon$ вплив на неї токсичних речовин, ендокринні порушення, неправильне харчування. Серед токсичних агентів особливе місце займає алкоголь [1]. Розвиток НАСГ у хворих на ожиріння спричиняється багатьма факторами (периферійна інсулінорезистентність, порушення толерантності до глюкози, гіперліпідемія, дисліпідемія, накопичення продуктів анаеробного гліколізу, ендотоксикоз, гепатотоксичність гіполіпідемічних засобів (статинів, фібратів) та фармакологічних засобів, що використовуються для зниження маси тіла, вживання $\beta$-адреноблокаторів) та низкою ще не встановлених факторів, вивчення яких наразі $\epsilon$ дуже актуальним [2].

Цікава в даному аспекті роль еритроцитів, які, з одного боку, відображають стан мембран гепатоцитів і $\epsilon$ «свідками» наростання фіброзу, а з іншого боку, зміни їх параметрів можуть призвести до прогресування цього процесу. У такому випадку клітини червоної крові, призводячи до порушень мікроциркуляції та тканинної гіпоксії, виступають як «винуватці» розвитку цирозу печінки. Отже, дослідження ймовірних факторів ризику та механізмів розвитку, клінічних особливостей перебігу хронічного стеатогепатиту на сьогоднішній день $\epsilon$ актуальним [3-5].
Мета дослідження - вивчити зміни основних показників червоної крові при стеатогепатитах різної етіології.

Матеріал і методи дослідження. В основі дослідження лежать клінічні спостереження за 60 хворими на алкогольну хворобу печінки та неалкогольний стеатогепатит. Серед обстежених пацієнтів було 53,3 \% чоловічої статі і 46,7 \% - жінок. Середній вік обстежуваних - 46 років. Усіх хворих було поділено на 2 групи. До першої групи (I) ввійшли 33 \% пацієнтів з алкогольною хворобою печінки (алкогольним стеатогепатитом). До другої групи (II) увійшли 67 \% хворих із неалкогольною жировою хворобою печінки (неалкогольний стеатогепатит). Контрольну групу склали 20 практично здорових осіб, у яких на момент обстеження не було ніяких гострих чи хронічних захворювань i, за даними анамнезу, не виявлено ніяких алергічних проявів. Усі пацієнти були репрезентативні за віком та статтю.

Крім збору анамнезу, фізичного обстеження, загальноприйнятих клінічних, лабораторних, біохімічних, інструментальних досліджень, здійснено низку сучасних інформативних методів дослідження.

Результати й обговорення. При дослідженні показників клінічного аналізу крові (табл. 1) вста- 
Огляди літератури, оригінальні дослідження, погляд на проблему, ювілеї новлено, що вміст еритроцитів у периферійній крові у хворих на неалкогольний стеатогепатит (НАСГ) був у межах норми, а у хворих на алкогольний стеатогепатит (АСГ) даний показник був вірогідно нижчий за показник у ПЗО на 9,0 \% (p<0,05).

Водночас, вміст гемоглобіну у хворих цієї ж групи вірогідно відрізнявся від вікової норми (табл. 1, рис. 1) і був істотно нижчий від показника у ПзО на 8,5\% (р<0,05), а це свідчить, що в частини хворих на АСГ було встановлено анемічний синдром.

Таблиця 1. Показники периферійної крові у хворих на стеатогепатит неалкогольного (НАСГ) та алкогольного генезу (АСГ) $(\mathrm{M} \pm \mathrm{m})$

\begin{tabular}{|c|c|c|c|}
\hline Показник & $\begin{array}{c}\text { Хворі на НАСГ } \\
(n=22)\end{array}$ & $\begin{array}{c}\text { Хворі на АСГ } \\
(n=18)\end{array}$ & $\begin{array}{c}\text { Практично здорові особи } \\
(\mathrm{n}=20)\end{array}$ \\
\hline Еритроцити (RBC), T/л & $3,78 \pm 0,01$ & $3,55 \pm 0,02 *$ & $3,9 \pm 0,01$ \\
\hline Гемоглобін (НGB), г/л & $128 \pm 1,2$ & $119 \pm 1,1^{*}$ & $130 \pm 1,3$ \\
\hline $\begin{array}{l}\text { Колірний показник (Color index } \\
\text { of blood) }\end{array}$ & $1,02 \pm 0,2$ & $1,01 \pm 0,1$ & $1,0 \pm 0,1$ \\
\hline Гематокрит (НСТ), \% & $41 \pm 1,1$ & $35 \pm 0,8^{*}$ & $39 \pm 1,0$ \\
\hline $\begin{array}{l}\text { Середній об'єм еритроцитів } \\
\text { (MCV), фл }\end{array}$ & $84 \pm 0,2^{*}$ & $96 \pm 0,4^{*}$ & $88 \pm 0,4$ \\
\hline $\begin{array}{l}\text { Середній вміст гемоглобіну в } \\
\text { еритроцитах (MCH), пг }\end{array}$ & $28 \pm 0,01 *$ & $35 \pm 0,02 *$ & $26 \pm 0,01$ \\
\hline $\begin{array}{l}\text { Середня концентрація } \\
\text { гемоглобіну в еритроцитах } \\
\text { (МСНС), г/дл }\end{array}$ & $32 \pm 0,02 *$ & $37 \pm 0,02 *$ & $33 \pm 0,01$ \\
\hline Лейкоцити (WBC), Г/л & $8,5 \pm 0,6$ & $10,1 \pm 1,1^{*}$ & $6,4 \pm 0,5$ \\
\hline Паличкоядерні нейтрофіли, \% & 4 & 7 & 5 \\
\hline Сегментоядерні нейтрофіли, \% & 46 & 68 & 52 \\
\hline Еозинофіли, \% & 2 & 4 & 2 \\
\hline Лімфоцити, \% & 48 & 21 & 41 \\
\hline Тромбоцити (PLT), Г/л & $220 \pm 1,1^{*}$ & $145 \pm 0,4^{*}$ & $176 \pm 1,2$ \\
\hline $\begin{array}{l}\text { Швидкість осідання } \\
\text { еритроцитів, мм/год }\end{array}$ & $18 \pm 1,2$ & $24 \pm 1,0$ * & $17 \pm 1,1$ \\
\hline
\end{tabular}

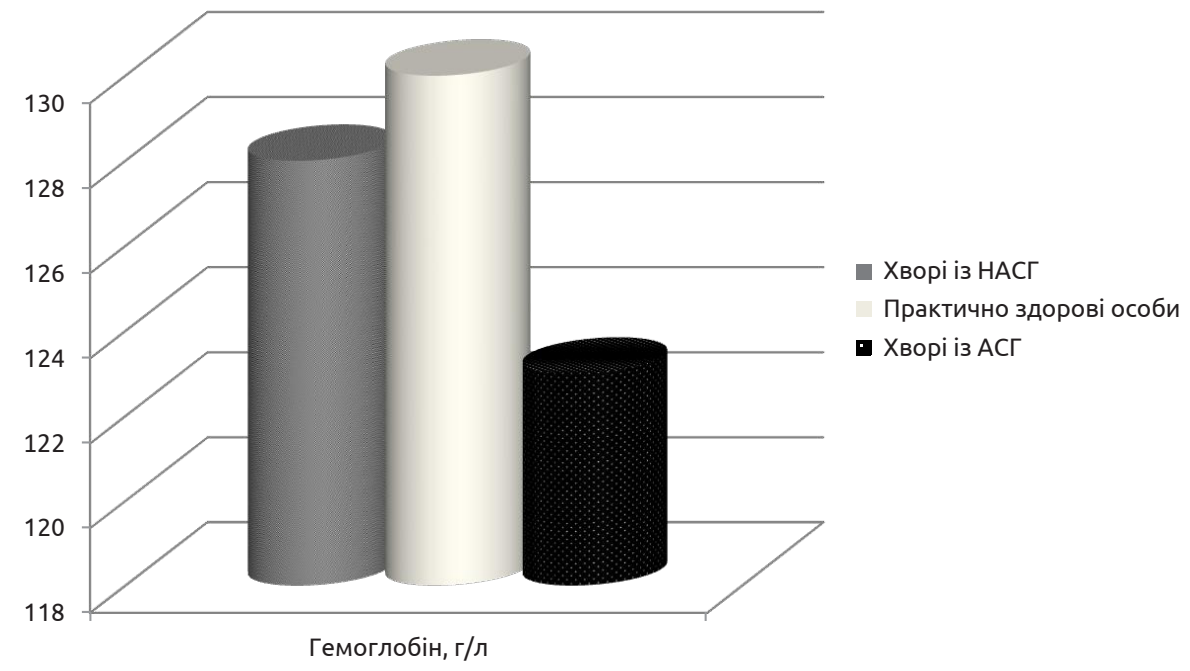
(ACГ).

Рис. 1. Вміст гемоглобіну в крові у хворих на стеатогепатит неалкогольного (НАСГ) та алкогольного генезу

Дійсно, при аналізі показників у 5 хворих на АСГ (25\% пацієнтів), у яких середній показник вмісту гемоглобіну склав $(107 \pm 1,1)$ г/л, було встановлено анемічний синдром, причому в $15 \%$ випадків - було верифіковано $\mathrm{B}_{12}$-дефіцитну анемію легкого ступеня, а в 10 \% - гемолітичну анемію, що розвинулась на тлі синдрому Ціве.

Показник гематокриту в обстежених хворих був вірогідно змінений лише в групі хворих на АСГ (див. табл. 1), де показник був нижчий від по- 
Огляди літератури, оригінальні дослідження, погляд на проблему, ювілеї

казника у ПЗО на $10,3 \%(p<0,05)$ і вказував на латентну анемію.

При аналізі середнього об'єму еритроцитів встановлено його різноспрямовані зміни. Так, у хворих на НАСГ показник був нижчий від даних у ПЗО на $9,5 \%(p<0,05)$, а у хворих на АСГ - вищим від П3О на $9,1 \%(p<0,05)$.

Водночас, середній вміст гемоглобіну в еритроцитах також вірогідно зростав у хворих обох груп порівняння: відповідно, на 7,7 та 34,6 \% (p<0,05), із більш суттєвою різницею у пацієнтів з АСГ $(p<0,05)$ (див. рис. 1). Середня кількість гемоглобіну в еритроцитах хворих на АСГ також перевищила показник у ПЗО на 12,1 \% $(p<0,05)$ (табл. 1$)$, залишаючись нормальною у хворих на НАСГ $(p>0,05)$.

У зв'язку з наявністю анемічного синдрому в деяких хворих на АСГ ми встановили істотне зростання середнього показника ШОЕ в цій гру- пі, який перевищив показник у П30 1,4 раза $(p<0,05)$.

При аналізі інших показників гемограми було встановлено зміни в групі хворих на АСГ: зростання кількості лейкоцитів в одиниці об'єму крові (у $1,6$ раза $(p<0,05))$ та різноспрямовані зміни кількості тромбоцитів: у хворих на НАСГ - показник був вищим від показника у ПЗО у 1,3 раза $(p<0,05)$, а у хворих на АСГ - нижчим у 1,2 раза $(p<0,05)$.

Аналіз біохімічних показників транспорту заліза вказує на вірогідне зростання вмісту заліза в сироватці крові у вхорих на АСГ-у 1,6 раза $(p<0,05)$ (табл. 2) за наявності тенденції до його зростання у хворих на НАСГ (р>0,05). Слід зазначити, що інтенсивність ліпопероксидації (вміст МА в крові) перебуває у прямій кореляційній взаємозалежності із показником вмісту в крові заліза (при АСГ $r=0,77$, p<0,05, при НАСГ $r=0,64, p<0,05)$.

Таблиця 2. Біохімічні показники ферокінетики крові у хворих на стеатогепатит неалкогольного (НАCГ) та алкогольного генезу (АСГ) $(\mathrm{M} \pm \mathrm{m})$

\begin{tabular}{|l|c|c|c|}
\hline \multicolumn{1}{|c|}{ Показник } & $\begin{array}{c}\text { Хворі на НАСГ } \\
(\mathrm{n}=22)\end{array}$ & $\begin{array}{c}\text { Хворі на АСГ } \\
(\mathrm{n}=18)\end{array}$ & $\begin{array}{c}\text { Практично здорові особи } \\
(\mathrm{n}=20)\end{array}$ \\
\hline $\begin{array}{l}\text { Сироваткове залізо, } \\
\text { мкмоль/л }\end{array}$ & $24,2 \pm 1,1$ & $28,1 \pm 0,9^{*}$ & $18,6 \pm 2,2$ \\
\hline Феритин, нг/мл & $210 \pm 12,1$ & $223 \pm 12,4^{*}$ & $170 \pm 11,8$ \\
\hline Трансферин, г/л & $2,6 \pm 0,7$ & $2,8 \pm 0,3$ & $2,6 \pm 0,3$ \\
\hline $\begin{array}{l}\text { Насичення трансферину } \\
\text { залізом, \% }\end{array}$ & $24,8 \pm 0,3^{*}$ & $26 \pm 0,5^{*}$ & $22,3 \pm 0,4$ \\
\hline
\end{tabular}

Примітка. * - зміни вірогідні $(p<0,05)$ порівняно з показником у ПзО.

Показник вмісту феритину в крові також перевищував показник у ПЗО у 1,3 раза $(p<0,05)$ у хворих на АСГ, а у пацієнтів із НАСГ зміни були не вірогідні $(p>0,05)$. Показники насичення трансферину залізом були підвищені в обох групах спостереження: відповідно, при НАСГ та АСГ-на 11,2 та $16,6 \%$ ( $<20,05)$, що може свідчити на користь наявності синдрому перевантаження залізом [6-8].

Висновки. 1. Для хворих на неалкогольний стеатогепатит на тлі ожиріння характерною $є$ тенденція до підвищення $(p>0,05)$ показників вмісту заліза в сироватці крові, вмісту феритину та насичення трансферину залізом за відсутності клініколабораторних ознак анемії.

2. У хворих на алкогольний стеатогепатит встановлено вірогідне підвищення вмісту заліза в сироватці крові, вмісту феритину, насичення трансферину залізом, дефіцит вітаміну $\mathrm{B}_{12}(p<0,05)$ за наявності у 25,0 \% хворих анемічного синдрому легкого ступеня, у 15,0 \% осіб - зумовленого дефіцитом вітаміну $\mathrm{B}_{12}$ та у $10,0 \%$ - гемолізом еритроцитів (синдром Ціве).

\section{ЛІТЕРАТУРА}

1. Бабак О. Я. Фиброз печени: современные представления о механизмах, способах диагностики и лечения / О. Я. Бабак, Е. В. Колесникова, Н. А. Кравченко // Сучасна гастроентерологія. - 2009. - № 2 (46). - С. 5-7.

2. Скибчик В. А. Неалкогольна жирова хвороба печінки: сучасна діагностика / В. А. Скибчик, М. О. Войтович // Гепатологія. - 2015. - № 1. - С. 52-56.

3. Силивончик Н. Н. Неалкогольная жировая 6олезнь печени: роль нарушений метаболизма железа / Н. Н. Силивончик, Д. Ф. Одинец // Лечебное дело. 2011. - № 4.
4. Туманский В. А. Особенности депонирования разновалентного железа (Fe2+ и $\mathrm{Fe} 3+)$ в печени при алкогольном и неалкогольном стеатогепатите / В. А. Туманский, С. В. Фень // Патологія. - 2015. - № 3 (35). C. 41-48.

5. Mutual interaction between iron homeostasis and obesity pathogenesis / A. A. Nikonorova, M. G. Skalnayab, A. Tinkova [et al.] // Journal of Trace Elements in Medicine and Biology. - 2015. - Vol. 30. - P. 207-214.

6. Pathways underlying iron accumulation in human nonalcoholic fatty liver disease / E. Aigner, I. Theurl, 
Огляди літератури, оригінальні дослідження, погляд на проблему, ювілеї

M. Theurl [et al.] // Am. J. Clin. Nutr. - 2008. - Vol. 87. P. 1374-1383.

7. A new syndrome of liver iron overload with normal transferrin saturation / R. Moirand, A. M. Mortaji, O. Loréal [et al.] // Lancet. - 1997. - Vol. 349, No. 9045. - P. 95-97.
8. Iron in fatty liver and in the metabolic syndrome: $A$ promising therapeutic target / P. Dongiovanni, A. L. Fracanzani, S. Fargion, L. Valenti // J. Hepatol. - 2011. - Vol. 55. P. 920-932.

\section{REFERENCES}

1. Babak, O.la., Kolesnykova, E.V., \& Kravchenko, N.A. (2009). Fibroz pecheni: sovremennye predstavleniya o mekhanizmakh, sposobakh diagnostiky i lecheniya [Liver fibrosis: current understanding of the mechanisms, methods of diagnosis and treatment]. Suchasna hastroenterolohiia - Modern Gastroenterology, 2 (46), 5-7 [in Russian].

2. Skybchyk, V.A., \& Voitovych, M.O. (2015). Nealkoholna zhyrova khvoroba pechinky: suchasna diahnostyka [Non-alcoholic fatty liver disease: modern diagnosis]. Hepatolohiia - Hepatology, 1, 52-56 [in Ukrainian].

3. Sylyvonchyk, N.N., \& Odynets, D.F. (2011). Nealkoholnaya zhyrovaya bolezn pecheni: rol narusheniy metabolizma zheleza [Non-alcoholic fatty liver disease: the role of iron metabolism disorders]. Lechebnoe delo-Medical Business, 4 [in Russian].

4. Tumanskiy, V.A., \& Fen, S.V. (2015). Osobennosti deponirovaniya raznovalentnogo zheleza (Fe2+ y Fe3+) $v$ pecheni pri alkogolnom i nealkogolnom steatogepatite
[Peculiarities of the depositing of nonvalent iron (Fe2 + and $\mathrm{Fe} 3+$ ) in the liver during alcoholic and non-alcoholic steatohepatitis]. Patolohiia - Pathology, 3 (35), 41-48 [in Russuan].

5. Nikonorova, A.A., Skalnayab, M.G., \& Tinkova, A. (2015). Mutual interaction between iron homeostasis and obesity pathogenesis. Journal of Trace Elements in Medicine and Biology, 30, 207-214.

6. Aigner, E., Theurl, I., \& Theurl, M. (2008). Pathways underlying iron accumulation in human nonalcoholic fatty liver disease. Am. J. Clin. Nutr., 87, 1374-1383.

7. Moirand, R., Mortaji, A.M., \& Loréal, O. (1997). A new syndrome of liver iron overload with normal transferrin saturation. Lancet, 349 (9045), 95-97.

8. Dongiovanni, P., Fracanzani, A.L., Fargion, S., \& Valenti, L. (2011). Iron in fatty liver and in the metabolic syndrome: A promising therapeutic target. J. Hepatol., 55 920-932.

\title{
ИЗМЕНЕНИЯ ОСНОВНЫХ ПОКАЗАТЕЛЕЙ КРАСНОЙ КРОВИ У БОЛЬНЫХ СТЕАТОГЕАТИТОМ РАЗЛИЧНОЙ ЭТИОЛОГИИ
}

\author{
๑О. С. Хухлина, Т. Н. Антофийчук, Н. П. Антофийчук, Е. В. Каушанская
}

ВГУз Украины «Буковинский государственный медицинский университет», г. Черновцы

PЕЗЮМЕ. Основными причинами стеатогепатита печени являются воздействие на нее токсических веществ, эндокринные нарушения, неправильное питание. Особое место среди токсических агентов занимает алкоголь.

Цель - исследовать изменения основных показателей красной крови при стеатогепатите различной этиологии.

Материал и методы. Проведено клиническое наблюдение за 60 больными алкогольной болезнью печени и неалкогольным стеатогепатитом. Среди обследованных 53,3 \% составили мужчины, 46,7 \% - женщины. Всех больных поделили на две группы: первую (I) составили 33 \% пациентов с алкогольной болезнью печени (алкогольным стеатогепатитом - АСГ), вторую (II) - 67 \% пациентов с неалкогольной жировой болезнью печени (неалкогольный стеатогепатит - НАСГ). В контрольную группу вошли 20 практически здоровых лиц (ПзЛ), у которых не было выявлено острых или хронических заболеваний и аллергических реакций.

Результаты. При исследовании показателей клинического анализа крови установлено, что содержание эритроцитов в периферической крови больных НАСГ было в пределах нормы, а у больных АСГ данный показатель был достоверно ниже показателя у ПЗЛ на 9,0 \% (p<0,05). Вместе с тем, содержание гемоглобина у больных этой же группы достоверно отличалось от возрастной нормы и было существенно ниже показателя у П3Л на 8,5 \% $(p<0,05)$, а это свидетельствует, что у части больных АСГ установлен анемичний синдром.

Вывод. Течение алкогольного стеатогепатита в 25,0 \% случаев сопровождается анемичным синдромом легкой степени, несмотря на существенное достоверное повышение в сыворотке крови содержания железа, ферритина, насыщения трансферрина железом. Причем, у 15,0 \% больных АСГ анемия обусловлена дефицитом витамина $\mathrm{B}_{12}$ а у у 10,0 \% - гемолизом эритроцитов. Описано, что на фоне ожирения течение неалкогольного стеатогепатита характеризуется недостоверным ростом показателей содержания железа в сыворотке крови, содержания ферритина и насыщения трансферрина железом при отсутствии клинико-лабораторных признаков анемии.

КЛЮЧЕВЫЕ СЛОВА: неалкогольный стеатогепатит; алкогольный стеатогепатит; анемический синдром; ожирение. 

OF DIFFERENT ETIOLOGIES

\author{
๑O. S. Khukhlina, T. M. Antofiichuk, M. P. Antofiichuk, O. V. Kaushanska \\ Bukovyna State Medical University
}

SUMMARY. The main causes of liver steatohepatitis are exposure to toxic substances, endocrine disorders, and poor diet. A special place among toxic agents is alcohol.

The aim - to investigate changes in the main indicators of red blood with steatohepatitis of various etiologies.

Material and Methods. A clinical observation of 60 patients with alcoholic liver disease and non-alcoholic steatohepatitis was conducted. Among surveyed, $53.3 \%$ were men, $46.7 \%$ were women. All patients were divided into two groups: the group I accounted for $33 \%$ of patients with alcoholic liver disease (alcoholic steatohepatitis - ASH), the group II-67\% of patients with non-alcoholic fatty liver disease (nonalcoholic steatohepatitis - NASH). The control group consisted of 20 practically healthy individuals, in whom no acute or chronic diseases or allergic reactions were detected.

Results. In the study of the clinical blood analysis, it was found that the content of erythrocytes in the peripheral blood of NASH patients was within the normal range, and in patients with ASH, this indicator was significantly lower than that of the PEP by $9.0 \%(p<0.05)$. At the same time, the hemoglobin content in patients of the same group was significantly different from the age norm and was significantly lower than in practically healthy individuals by $8.5 \%$ $(p<0.05)$, and this indicates that some patients with ASH have anemic syndrome.

Conclusion. The course of alcoholic steatohepatitis in $25.0 \%$ of cases is accompanied by an anemic mild syndrome, despite a significant increase in serum iron content, ferritin, transferrin saturation with iron. Moreover, in $15.0 \%$ of patients with ASH, anemia is caused by vitamin $B_{12}$ deficiency, and in $10.0 \%$ - by erythrocyte hemolysis. It is described that on the background of obesity, non-alcoholic steatohepatitis is characterized by an unreliable increase in serum iron content, ferritin content and transferrin saturation with iron in the absence of clinical and laboratory signs of anemia.

KEY WORDS: non-alcoholic steatohepatitis; alcoholic steatohepatitis; anemic syndrome; obesity.

Отримано 30.01.2019 